\title{
EFFECT OF CUTTING HEIGHTS ON THE TURF AND PLAYING QUALITY TRAITS OF SOME TURF ALTERNATIVES IN A MEDITERRANEAN ENVIRONMENT
}

\author{
Ali SALMAN ${ }^{I *}$, Behcet $K^{2} R^{2}$, Riza AVCIOGLU ${ }^{2}$ \\ ${ }^{1}$ Ege University, Bayindir Vocational School, Izmir, Turkey \\ ${ }^{2}$ Ege University, Faculty of Agriculture, Department of Field Crops, Izmir, TURKEY \\ *Corresponding author: ali.salman@ege.edu.tr
}

Received: 04.09.2019

\begin{abstract}
The purpose of this study was to detect the agronomic and sports field characteristics of some turf type tall fescue and traditional cool season sports turf mixture mowed at different heights in a Mediterranean environment. The trial was carried out in the experimental fields of Bayindir Vocational School, Izmir (Turkey), using three different turf alternatives under 12, 22 and $32 \mathrm{~mm}$ mowing height regime. Visual turf quality, texture and weed invasion traits were determined and shock absorption and vertical deformation were also measured as playing quality parameters for sports turf.

Turf alternatives of tall fescue except traditional cool season sports turf mixture showed an adaptation to low mowing height which increased shoot density and promoted a finer leaf texture. Shock absorption and vertical deformation traits were significantly affected by mowing heights; the highest value was recorded for the lowest mowing heights. Nevertheless, a good sports field quality was determined for the tall fescue and tall fescue + perennial ryegrass plots. The results of the present work showed that tall fescue, if maintained at low mowing height regime, could provide a dense and fine textured turf suitable for sport fields with a high visual turf quality.
\end{abstract}

Key words: Mowing regime, perennial ryegrass, sports field turf and quality, tall fescue

\section{INTRODUCTION}

Among cool season turf grass species Festuca arundinacea Schreb., is considered as the most tolerant to high temperature, drought and salinity (Huang and Gao, 2000), while its deep rooting, shade adaptation, wear resistance and weed competition are appreciated by turf managers. However, it isn't popular to use in sport fields turf yet due to the low tolerance to low mowing height (Moore and Christians, 1989) and partial withering of leaves during winter period (Dernoeden et al., 1993). Recent releases of dwarf-type cultivars are currently spreading and management aspects such as mowing height and frequency as well as nutrient inputs should be reconsidered according to their reduced growth rate (Miele et al., 2002; Reicher and Throssell, 1991; Powell and Tapp, 1988). The objective of this study was to evaluate the visual turf quality and playing characteristics of turf alternatives such as pure tall fescue, tall fescue + perennial ryegrass mixture and traditional sports field turf mixture for sport fields in a Mediterranean environment.

\section{MATERIALS AND METHODS}

The trial was conducted on the experimental field located of Bayindir Vocational School, Ege University,
Izmir, Turkey in 2012, 2013 and 2014. Mediterranean type climate dominated in the experimental area with the average of long years was $16,6{ }^{\circ} \mathrm{C}$ for temperature and $623,8 \mathrm{~mm}$ for rainfall (Anonymous, 2014). The soil of experimental area was loamy sand textured with the following characteristics; ph 5,83; total $\left(\mathrm{CaCO}_{3}\right)$ 0,82\%; total nitrogen (Kjeldahl) 0,092 \%; organic matter 2,27 ppm; available phosphorus 2,54 ppm: exchangeable potassium $40 \mathrm{ppm}$. At the beginning of September, the seedbed was made by disrupting a vegetable fellow with a moldboard, ploughed at $25 \mathrm{~cm}$ deep. Before this preparation, the experimental plots were equipped with a permanent pipeline system using rotary sprinklers. During the summer season, supplemental irrigation has been carried out when necessary to prevent visual wilt of the turf by sprinkling. In the first week of November of the year 2012, nitrogen, phosphorus and potassium fertilizers were applied at a rate of $75 \mathrm{~kg} \mathrm{ha}^{-1} \mathrm{~N}, 50 \mathrm{~kg} \mathrm{ha}^{-1} \mathrm{P}_{2} \mathrm{O}_{5}$ and $50 \mathrm{~kg} \mathrm{ha}^{-1} \mathrm{~K}_{2} \mathrm{O}$, respectively, before seeding and levelling the soil with a cultivator and harrow.

The experiment was conducted in a factorial randomized complete block design with four replications. Three turf grass alternatives [Festuca arundinacea $(\mathrm{Fa})$ $\% 100$, Festuca arundinacea $(\mathrm{Fa}) \% 60+$ Lolium perenne 
(Lp) \%40 and traditional cool season sports turf mixture; Lolium perenne (Lp) 50\%, Festuca rubra var. rubra (Frr) $20 \%$, Festuca ovina (Fo) 10\%, Festuca rubra commutate (Frc) $10 \%$, Poa pratensis (Pp) 10\%] were tested in the trial. Plot size was $2 \mathrm{~m}$ wide by $12 \mathrm{~m}$ long and no bare soil corridor was maintained between plots. As an experimental factor, horizontal mowing practices in three different cutting heights (12 mm, $22 \mathrm{~mm}$ and $32 \mathrm{~mm})$ were performed on the turf cover. The first mowing was made by a vertical mover (Husqvarna R52S) 6 weeks after sowing. Invading weeds were removed during the establishment period by hand when necessary. However, after the turfs were fully established the area, weeds were allowed to invade as the competition evolved better with grass cultivars.

The following measurements were maintained during the trial. Visual turf quality trait was assessed by a visual score based on a 1-9 scale, as recommended in the National Turf grass Evaluation Program (NTEP) in the USA (Morris and Sherman, 1998). Texture measurements were taken by examining leaf blade samples from 5 different parts of each plot. The leaf blades width was measured and classified as $<1 \mathrm{~mm}$ very fine, 1-2 mm fine, 2-3 mm medium, 3-4 mm coarse and $>4 \mathrm{~mm}$ very coarse (Beard, 1973). Observations and scoring were maintained on a monthly basis, and summarized as two years average. Weed invasion was examined and classified on a scale of 1 to 5 with 1 indicating an excessive amount of weed presence and 5, a complete absence (Beard, 1973). Sports field characteristics like shock absorption (\%) and vertical deformation $(\mathrm{mm})$ were measured on the plots in accordance with FIFA standards (FIFA, 2005) benefiting from "Club Set" of Deltec Metaal. All data except visual turf quality and weed invasion were analyzed statistically (Acikgoz et al., 2004) and for shock absorption, arcsine transformation were used and significant means were compared by the LSD test at 5\% probability level as described by Steel and Torrie (1980).

\section{RESULTS AND DISCUSSION}

Visual Turf Quality (1-9 point)

The visual turf quality trait as the composite of colour, uniformity and texture traits is a widely used criterion to define the overall performances of turfs in turf management practices. The results revealed that, the mixture of $60 \% \mathrm{Fa}+40 \% \mathrm{Lp}$ had the highest value in 32 $\mathrm{mm}$ mowing height in winter and spring seasons and the highest visual turf quality (8.71), whereas the traditional cool season sports turf mixture had the average of 5.38 points under $12 \mathrm{~mm}$ mowing height in summer displaying very limited quality (Table 1 ). It was also observed that as the mowing height increased, the quality scores also increased and different turf alternatives showed differences as the average of different seasons. For example, $60 \% \mathrm{Fa}+40 \% \mathrm{Lp}$ mixture yielded the best quality values with a mean of 8,52 points in spring. However, traditional cool season sports turf mixture had an average of 6,38 points in winter. As we considered the values of visual turf qualities in different mowing heights, we concluded that $32 \mathrm{~mm}$ height practice had reached the highest turf quality value with a general average score of 7.95 , while it can also observed the $22 \mathrm{~cm}$ mowing height with a score of 7.84, although the practices of the mowing height of $12 \mathrm{~cm}$ could reach only 7.33 points.

Table 1. Visual turf quality and texture traits of some turf alternatives cut at different heights

\begin{tabular}{|c|c|c|c|c|c|c|c|c|c|c|c|}
\hline \multirow{2}{*}{$\begin{array}{c}\text { Turf } \\
\text { Alternatives }\end{array}$} & \multirow{2}{*}{$\begin{array}{c}\text { Mowing } \\
\text { Heights } \\
(\mathbf{m m})\end{array}$} & \multicolumn{5}{|c|}{ Visual Turf Quality (1-9) } & \multicolumn{5}{|c|}{ Texture (mm) } \\
\hline & & Winter & Spring & $\underline{\text { Summer }}$ & $\underline{\text { Autumn }}$ & $\underline{\text { Mean }}$ & Winter & Spring & $\underline{\text { Summer }}$ & $\underline{\text { Autumn }}$ & $\underline{\text { Mean }}$ \\
\hline \multirow{3}{*}{$\begin{array}{c}\text { Tall Fescue } \\
100 \%\end{array}$} & 12 & 8,13 & 8,10 & 7,70 & 7,60 & 7,88 & 2,83 & 2,45 & 2,30 & 2,56 & 2,54 \\
\hline & 22 & 8,07 & 8,11 & 8,22 & 8,04 & 8,11 & 2,97 & 3,14 & 2,63 & 2,84 & 2,89 \\
\hline & 32 & 8,69 & 8,63 & 8,38 & 8,20 & 8,48 & 3,63 & 3,38 & 3,00 & 3,24 & 3,31 \\
\hline \multicolumn{2}{|c|}{ Mean } & 8,30 & 8,28 & 8,10 & 7,95 & 8,16 & 3,14 & 2,99 & 2,64 & 2,88 & 2,91 \\
\hline \multirow{3}{*}{$\begin{array}{c}\text { Tall Fescue } \\
60 \% \text { P. } \\
\text { Ryegrass } \\
\% 40\end{array}$} & 12 & 8,08 & 8,29 & 8,26 & 8,03 & 8,17 & 2,03 & 2,13 & 2,34 & 2,46 & 2,24 \\
\hline & 22 & 8,62 & 8,57 & 8,37 & 8,25 & 8,45 & 2,44 & 2,28 & 2,18 & 2,47 & 2,34 \\
\hline & 32 & 8,71 & 8,71 & 8,65 & 8,32 & 8,60 & 2,93 & 2,71 & 2,23 & 2,66 & 2,64 \\
\hline \multicolumn{2}{|c|}{ Mean } & 8,47 & 8,52 & 8,43 & 8,20 & 8,40 & 2,47 & 2,38 & 2,26 & 2,53 & 2,41 \\
\hline \multirow{3}{*}{$\begin{array}{c}\text { Traditional } \\
\text { Cool Season } \\
\text { Sports Turf } \\
\text { Mixture }\end{array}$} & 12 & 5,87 & 6,07 & 5,38 & 6,39 & 5,93 & 1,83 & 1,98 & 1,88 & 2,10 & 1,95 \\
\hline & 22 & 6,53 & 7,38 & 7,13 & 6,78 & 6,95 & 2,17 & 2,44 & 2,26 & 2,41 & 2,32 \\
\hline & 32 & 6,76 & 6,74 & 6,60 & 6,95 & 6,76 & 2,42 & 2,48 & 2,43 & 2,57 & 2,47 \\
\hline \multicolumn{2}{|c|}{ Mean } & 6,38 & 6,73 & 6,37 & 6,71 & 6,55 & 2,14 & 2,30 & 2,19 & 2,36 & 2,25 \\
\hline \multirow{3}{*}{$\begin{array}{c}\text { General } \\
\text { Mean }\end{array}$} & 12 & 7,36 & 7,49 & 7,11 & 7,34 & 7,33 & 2,23 & 2,19 & 2,18 & 2,37 & 2,24 \\
\hline & 22 & 7,74 & 8,02 & 7,90 & 7,69 & 7,84 & 2,53 & 2,62 & 2,35 & 2,57 & 2,52 \\
\hline & 32 & 8,05 & 8,03 & 7,88 & 7,82 & 7,95 & 2,99 & 2,86 & 2,56 & 2,82 & 2,81 \\
\hline \multicolumn{2}{|c|}{ Mean } & 7,72 & 7,84 & 7,63 & 7,62 & 7,70 & 2,58 & 2,56 & 2,36 & 2,59 & 2,52 \\
\hline \multicolumn{2}{|c|}{ LSD (\%5): } & & & & & & \multicolumn{5}{|c|}{$\begin{array}{l}\text { TA: 0,04 MH: 0,04 S: 0,05 TAxMH: } 0,07 \\
\text { TAxS: 0,09 MHxS: 0,09 TAxMHxS: 0,15 }\end{array}$} \\
\hline
\end{tabular}


In this section, as the results were compared in terms of turf alternatives; we recorded that the mixture of $60 \%$ $\mathrm{Fa}+40 \% \mathrm{Lp}$ gave the best result with an average score of 8.40 and followed by $100 \%$ Fa turf alternative with an average of 8.16. The traditional cool season sports turf mixture could only have an average of 6.55 visual turf quality score. We suggested that, $60 \% \mathrm{Fa}+40 \% \mathrm{Lp}$ mixture performed best, containing $40 \%$ of Lolium perenne which have narrow leaf blades forming favorable texture, whereas due to the traditional cool season sports turf mixture containing \% 50 Lolium perenne had limited cover, uniformity and weed invasion ratio scores and accordingly, visual turf quality scores were also poor.

The visual turf quality scores displayed that Festuca arundinacea plots had high quality scores in each season due to the ability of crop to establish a uniform and dense turf cover under Mediterranean climate. Although the medium rough texture of Festuca arundinacea, purely sown plots had also satisfactory quality scores. Similsr results optained by Uzun and Bilgili (2011), Demiroglu et al. (2010), Kir et al. (2010) and Salman and Avcioglu (2008).

We also detected that the quality scores increased with the increasing height of mowing except in some very few cases and also recorded that the relatively thick leaf blades and thinner stems under higher mowing practice provided better quality appearances. Similar results were reported by Volterrani and Magni (2004) in under Mediterranean climates.

It was also recorded that different turf alternatives statistically differed in performance as averages of different seasons. In particular, we suggested that the depression of the traditional cool season sports turf mixture option in terms of all characteristics under stress conditions of summer season caused these differences. Pure Festuca arundinacea and mixed turf option containing Festuca arundinacea, were the best performing turf alternatives due to the superior adaptability of this turf grass to the Mediterranean Summer conditions (Salman et al., 2011; Demiroglu et al., 2010).

\section{Texture ( $\mathrm{mm})$}

Turf grass texture is a function of the width of individual leaves. A medium-fine to medium texture, ranging from 1.5 to $3 \mathrm{~mm}$ in width is generally preferred for most turf grass uses (Beard, 1973). The results related to texture scores of turf alternatives under three different mowing heights and statistical parameters were given in Table 1. The variation analyses highlighted that the main effects (turf alternatives and mowing heights) and interactions were significant. In the evaluation of the texture, $100 \%$ Festuca arundinacea turf option had the highest value under $32 \mathrm{~mm}$ mowing height and $3.63 \mathrm{~mm}$ leaf width in winter. While the traditional cool season sports turf mixture option under $12 \mathrm{~mm}$ mowing height in same season had the thinnest leaf texture with an average of $1.83 \mathrm{~mm}$. The results of the season $\mathrm{x}$ mowing height interaction effect showed that the $100 \%$ Fa turf option in winter had higher average value with an average of 3.14 $\mathrm{mm}$, while traditional cool season sports turf mixture had the thinnest leaf blades with a mean value of $2.14 \mathrm{~mm}$ in same season. The results of texture values for all turf alternatives showed that, the value of the texture also increased, in another word, the leaf blade width gradually increased as the mowing height increased.

When the texture values were compared as seasonal averages; the lowest average leaf width was obtained as a mean of $2.36 \mathrm{~mm}$ in summer, but in winter, spring and autumn, significantly higher average texture values were found as $2.58 \mathrm{~mm}, 2.56 \mathrm{~mm}$ and $2.59 \mathrm{~mm}$, respectively.

We concluded that the $100 \% \mathrm{Fa}$ turf option had the highest value as $2.91 \mathrm{~mm}$ average when the texture results were compared as turf alternatives. The mixture of $60 \%$ $\mathrm{Fa}+40 \% \mathrm{Lp}$ with a $2.41 \mathrm{~mm}$ texture value and the traditional cool season sports turf mixture with $2.25 \mathrm{~mm}$ average followed the pure Fa option.

As it is well known, the "texture" feature of turfs in symbolized by the width of the leaf blades of turf grasses, is a feature that enhances the appearance of the turf plots and exhibits the "fine" texture structure in narrow-leaf leaved grasses. In this respect, Festuca arundinacea; which has a rough or moderately rough texture property depending on the different cultivars which are genetically coarse or rough textured grass, displayed clearly the characteristics mentioned in this part of our study. Volteranni and Magni (2004) and Avcioglu (1997) described another superior characteristic of Festuca arundinacea; adaptability of this grass to the hot Mediterranean climate, although it is a cool season grass. They also stated that new Festuca arundinacea cultivars with fine texture were improved in many countries, since old rough textured Festuca arundinacea cultivars were not being required by customers.

By the Lolium perenne taking place in traditional cool season sports turf mixture, a relatively fine textured turf cover was obtained. The effect of mowing heights on the texture was clearly monitored and as the mowing height increased, generally in all turf options, a definite inclination towards the medium or coarse texture were recorded. This modification behavior of turf crops is caused by the leaf and stem loses of crops which stimulate the production of smaller cells and dense tissues resulting in smaller leaves and thinner stems as a self-protection mechanism. Researchers like Bilgili and Acikgöz (2011), Avcioglu (1997), Salisbury and Ross (1992) and Watschke and Schmidt (1992) explained the basis of these morphological modifications of turf grasses.

In this part of the study, in the traditional cool season sports turf mixture which was not commented as a favorable option in terms of many features, quite good texture scores have been determined due to the mixture component such as Lolium perenne, Poa pratensis, Festuca rubra, Festuca rubra commutata and Festuca ovina which are fine-textured grass species. 


\section{Force Reduction (Shock absorption, \%)}

The findings of the force reduction $(\%)$ trait of turf alternatives experimented under different mowing heights are summarized in Table 2. Results of the analysis indicated that turf alternative $\mathrm{x}$ mowing height $\mathrm{x}$ season triple interaction was not significant, whereas all binary interactions and factors were significant. Accordingly, the average percentage of the highest force reduction value in the experiment was $69.17 \%$ during the spring measurements of the $100 \%$ Fa turf option, whereas the mean $49.44 \%$ force reduction as the lowest value was obtained from traditional cool season sports turf mixture in summer. The force reduction performance of the turf alternatives at different mowing heights also differed statistically and the smallest force reduction percentage was recorded in traditional cool season sports turf mixture option as $51.92 \%$ in $12 \mathrm{~mm}$ mowing height, whereas the force reduction value of $100 \%$ Fa turf option increased to $69.93 \%$ in $32 \mathrm{~mm}$ mowing height. Our findings in force reduction feature showed that seasonal averages also varied considerably, being highest average value of 64.66 $\%$ in autumn and $60.91 \%$ in summer (Table 2).

Table 2. Force reduction and vertical deformation traits of some turf alternatives cut at different heights

\begin{tabular}{|c|c|c|c|c|c|c|c|c|c|c|c|}
\hline \multirow{2}{*}{$\begin{array}{c}\text { Turf } \\
\text { Alternatives }\end{array}$} & \multirow{2}{*}{$\begin{array}{l}\text { Mowing } \\
\text { Heights } \\
(\mathrm{mm})\end{array}$} & \multicolumn{5}{|c|}{ Force Reduction (Shock Absorption, \%) } & \multicolumn{5}{|c|}{ Vertical Deformation (mm) } \\
\hline & & $\underline{\text { Winter }}$ & Spring & $\underline{\text { Summer }}$ & $\underline{\text { Autumn }}$ & $\underline{\text { Mean }}$ & Winter & Spring & $\underline{\text { Summer }}$ & $\underline{\text { Autumn }}$ & $\underline{\text { Mean }}$ \\
\hline \multirow{3}{*}{$\begin{array}{c}\text { Tall Fescue } \\
100 \%\end{array}$} & 12 & 64,33 & 66,50 & 66,67 & 59,00 & 64,13 & 4,65 & 5,95 & 6,63 & 5,90 & 5,78 \\
\hline & 22 & 66,83 & 69,67 & 66,17 & 65,67 & 67,08 & 4,90 & 5,70 & 6,08 & 5,67 & 5,59 \\
\hline & 32 & 67,67 & 71,33 & 69,83 & 69,67 & 69,63 & 5,72 & 6,40 & 7,28 & 5,85 & 6,31 \\
\hline \multicolumn{2}{|c|}{ Mean } & 66,28 & 69,17 & 67,56 & 64,78 & 66,94 & 5,09 & 6,02 & 6,67 & 5,81 & 5,89 \\
\hline \multirow{3}{*}{$\begin{array}{c}\text { Tall Fescue } \\
60 \% \text { P. } \\
\text { Ryegrass } \\
\% 40\end{array}$} & 12 & 68,67 & 67,67 & 63,67 & 63,83 & 65,96 & 5,18 & 5,43 & 6,43 & 6,15 & 5,80 \\
\hline & 22 & 65,17 & 68,50 & 68,00 & 70,00 & 67,92 & 5,15 & 5,30 & 6,87 & 6,00 & $\mathbf{5 , 8 3}$ \\
\hline & 32 & 65,00 & 66,00 & 65,50 & 70,67 & 66,79 & 5,87 & 6,28 & 7,40 & 5,90 & 6,36 \\
\hline \multicolumn{2}{|c|}{ Mean } & 66,28 & 67,39 & 65,72 & 68,17 & 66,89 & 5,40 & 5,67 & 6,90 & 6,02 & 6,00 \\
\hline \multirow{3}{*}{$\begin{array}{c}\text { Traditional } \\
\text { Cool Season } \\
\text { Sports Turf } \\
\text { Mixture }\end{array}$} & 12 & 52,17 & 48,83 & 48,33 & 58,33 & 51,92 & 3,90 & 5,80 & 5,50 & 5,77 & 5,24 \\
\hline & 22 & 50,83 & 55,17 & 50,17 & 62,50 & 54,67 & 4,03 & 4,80 & 5,82 & 5,83 & 5,12 \\
\hline & 32 & 48,83 & 52,83 & 49,83 & 61,33 & 53,21 & 4,55 & 5,32 & 6,18 & 5,85 & 5,48 \\
\hline \multicolumn{2}{|c|}{ Mean } & 50,61 & 52,28 & 49,44 & 60,72 & 53,26 & 4,16 & 5,31 & $\mathbf{5 , 8 3}$ & 5,82 & 5,28 \\
\hline \multirow{3}{*}{$\begin{array}{l}\text { General } \\
\text { Mean }\end{array}$} & 12 & 61,72 & 61,00 & 59,56 & 60,39 & 60,67 & 4,58 & 5,73 & 6,19 & 5,94 & 5,61 \\
\hline & 22 & 60,94 & 64,44 & 61,44 & 66,06 & 63,22 & 4,69 & 5,27 & 6,26 & 5,83 & 5,51 \\
\hline & 32 & 60,50 & 63,39 & 61,72 & 67,22 & 63,21 & 5,38 & 6,00 & 6,96 & 5,87 & 6,05 \\
\hline \multicolumn{2}{|c|}{ Mean } & 61,06 & 62,94 & 60,91 & 64,56 & 62,37 & 4,88 & 5,66 & 6,47 & 5,88 & 5,72 \\
\hline \multicolumn{2}{|c|}{ LSD (\%5): } & \multicolumn{5}{|c|}{$\begin{array}{l}\text { TA: 1,04 MH: 1,04 S: 1,21 TAxMH: 1,81 } \\
\text { TAxS: 2,09 MHxS: 2,09 TAxMHxS: ns }\end{array}$} & \multicolumn{5}{|c|}{$\begin{array}{l}\text { TA: } 0,11 \mathrm{MH}: 0,11 \mathrm{~S}: 0,13 \text { TAxMH: } 0,20 \\
\text { TAxS: 0,23 MHxS: 0,23 TAxMHxS: 0,40 }\end{array}$} \\
\hline
\end{tabular}

TA: Turf Alternatives, MH: Mowing Height, S: Season

Saunders et al. (2011) and Baker and Canaway (1993) displayed that hard turf surface can crush the joints (ankle, hip and spine) and cartilage by compressing and may cause soft tissue bruising on the muscles of the falling player. Excessive effect may also result in fracture of the bones, whereas, athletes may get tired more easily on very soft grass surfaces. The human body also acts as a spring on the contact surface (Orchard, 2002), and the athlete who moves on the grass surface applies a certain amount of force to this surface and the ability of this surface to absorb a significant portion of the effect of the force is defined as Shock absorption (Brosnan et al., 2009; FIFA, 2009a, 2009b; Volteranni and Magni, 2004). This feature, also referred to as Force Reduction-Power Reduction of grass surfaces, is defined by the unit of \%. For example, the high Power Reduction value (\%) means Soft Surface and the ideal absorption power value for natural turf reaches to $60-70 \%$. The lower limit of this value can be accepted up to $55 \%$ for relatively low quality lawns.
In the evaluations, it was concluded that the value of the highest power reduction, (\% 100) were determined in Festuca arundinacea and $60 \% \mathrm{Fa}+40 \% \mathrm{Lp}$ mixtures with different mowing heights and the high adaptability of Festuca arundinacea in the blends was found to play the most important role (Martinello and Andrea, 2006). Since existing in the pure or mixed turfs, this plant formed a strong grass cover which means soft soil surface absorbing a high share of applied force. Ozkan et al. (2014) and Volterrani and Magni (2004) also pointed out similar results.

The force reduction performance of the turf options at different mowing heights showed statistically significant differences and the traditional cool season sports turf mixture had the lowest values and the averages of different mowing heights below the standards. These results were caused by the traditional cool season sports turf mixture could not adapt to the regional conditions and the poor grass cover. Many researchers concluded that 
cool season turf grass mixtures could not be successful in many aspects under the Mediterranean ecology (Harivandi et al., 2008; Martinello and Andrea, 2006).

\section{Vertical Deformation ( $\mathrm{mm}$ )}

Vertical deformation is a measure of how much a sports turf surface gives response to player pressure. Surfaces that are too soft (high vertical deformation) absorb most of the energy athletes exert when running and that energy is not returned back to the athlete. Playing on a surface with high vertical deformation can be like running on a beach sand and requires a great consumption of energy. Athletes exerting more energy on a soft surface will become tired sooner and will either require greater periods of rest or be subject to fatigue injuries such as pulled muscles. Surfaces that are too firm (low vertical deformation) are hard and unforgiving and can create discomfort or injury.

The research results on the vertical deformation feature are given in Table 2. According to the results of the statistical analysis, effect of triple interaction, binary interaction and factors were found significant. The mixture of $60 \% \mathrm{Fa}+40 \% \mathrm{Lp}$ had the highest $(7.40 \mathrm{~mm})$ vertical deformation value under $32 \mathrm{~mm}$ mowing height during Summer period. On the other hand, the traditional cool season sports turf mixture option had the lowest value of vertical deformation as $3.90 \mathrm{~mm}$ under $12 \mathrm{~mm}$ mowing height regime. When the data were analyzed in this concept for the performance of turf alternatives under different mowing heights, the mixture of $60 \% \mathrm{Fa}+40 \%$ Lp reached the highest average value of 6.32 under $32 \mathrm{~mm}$ mowing height, while traditional cool season sports turf mixture average of 5.12 of vertical deformation value under $22 \mathrm{~mm}$ mowing height was observed to be the lowest level. When the values were considered as average of season; the lowest average value was obtained with $4.88 \mathrm{~mm}$ in winter, while the average vertical deformation value in summer was the highest as $6.47 \mathrm{~mm}$.

When the results of turf alternatives were compared, $60 \% \mathrm{Fa}+40 \% \mathrm{Lp}$ mixture reached the highest average value of 6.00 , while the traditional cool season sports turf mixture remained at the lowest average vertical deformation value of $5.28 \mathrm{~mm}$ (Table 2).

In the sports turf grounds, an extremely deformed surface is called "unstable" and directly affects the athlete's "Running Style", and so athlete should shorten his steps to secure himself and as a natural consequence, his speed decreases. On a none-deformed surface, due to the hardness and slippage, an unsafe movement medium is formed ultimately annoying the athlete (Orchard, 2002). For this reason, it is expected formation of a Vertical Deformation between a given boundary on the sport turfs and the formation of $2-4 \mathrm{~mm}$ deformation on the grass stand is accepted as the most desirable values in the sports surveys in England. In case of deformations of $10 \mathrm{~mm}$ or more, the surface is defined as over-risky (corrugated) ( Baker and Canaway,1993; FIFA, 2009a, 2009b). In FIFA standards, $9 \mathrm{~mm}$ is accepted as maximum level in standard turf stands. Whereas $4-8 \mathrm{~mm}$ range is adopted as ideal on high maintenance sports turf surfaces.

In this part of the study, "Vertical Deformation" values determined in different seasons and different mowing heights in all turf options were found to be between the upper and lower limit values of the standards described by British and FIFA standards. The millimetric deformation values did not show a linear distribution as the mowing height differed depending on the turf options, deformation values did not display a stable variation in different seasons. In this section, generally higher vertical deformation values were recorded in $100 \%$ Festuca arundinacea and $60 \% \mathrm{Fa}+40 \% \mathrm{Lp}$ turf mixture options. Similar results were also determined in terms of mowing heights and increasing rate of deformation was observed with the increasing strength of the turf cover under higher mowing heights (Ozkan et al., 2014; Miller, 2004 and Miele et al., 2002).

\section{Weed invasion (1-5 point)}

According to values related to weed invasion, $100 \%$ Fa turf alternative showed a full or almost full score (5.00) of weed invasion values at all seasons and mowing heights, whereas the average value of traditional cool season sports turf mixture option score decreased to 2,97 points in autumn under $32 \mathrm{~mm}$ mowing height (Table 3 ). The $60 \% \mathrm{Fa}+40 \% \mathrm{Lp}$ mixture turf option followed the $100 \% \mathrm{Fa}$ option and had the scores close to full points (5.00) in all seasons and mowing heights, except in autumn under $12 \mathrm{~mm}$ mowing height. In the study, the weed invasion scores were 5.00, 4.98 and 4,98 in $100 \% \mathrm{Fa}$ option, whereas the scores were $3.45,3.51$ and 3.32 , respectively in the traditional cool season sports turf mixture, remaining at very low values. When the weed invasion scores were considered as seasonal averages of different seasons, it was commented that the higher average scores were reached to 4.54 and 4.53 , respectively in winter, while lower values were detected in summer (4.38) and autumn (4.27).

The 100\% Festuca arundinacea turf option showed full or almost full scores in generally all seasons in the evaluation of weed invasion. The $60 \% \mathrm{Fa}+40 \% \mathrm{Lp}$ mixture turf option was also ranked second after $100 \%$ Festuca arundinacea option. Our findings related to the weed invasion scores of the turf options tested in our study revealed that, due to the high adaptability of Festuca arundinacea and aggressive growth of this grass, all $\mathrm{Fa}$ containing mixture options had very high scores (Beard, 1973). Namely, Festuca arundinacea became dominant with its high competitive capacity in the mixtures and it did not give any chance to invading weeds to grow. 
Table 3. Weed invasion trait of some turf alternatives cut at different heights

\begin{tabular}{|c|c|c|c|c|c|c|}
\hline \multirow{2}{*}{ Turf Alternatives } & \multirow{2}{*}{$\begin{array}{c}\text { Mowing Heights } \\
(\mathbf{m m})\end{array}$} & \multicolumn{5}{|c|}{ Weed Invasion (1-5) } \\
\hline & & Winter & Spring & Summer & Autumn & Mean \\
\hline \multirow{3}{*}{ Tall Fescue $100 \%$} & 12 & 5,00 & 5,00 & 5,00 & 5,00 & 5,00 \\
\hline & 22 & 5,00 & 4,96 & 4,96 & 4,98 & 4,98 \\
\hline & 32 & 5,00 & 4,96 & 5,00 & 4,96 & 4,98 \\
\hline Mean & & 5,00 & 4,97 & 4,99 & 4,98 & 4,98 \\
\hline \multirow{3}{*}{ Tall Fescue $60 \%$ P. Ryegrass $\% 40$} & 12 & 4,63 & 5,00 & 4,75 & 4,49 & 4,72 \\
\hline & 22 & 5,00 & 5,00 & 5,00 & 4,78 & 4,95 \\
\hline & 32 & 5,00 & 5,00 & 5,00 & 4,91 & 4,98 \\
\hline Mean & & $\mathbf{4 , 8 8}$ & 5,00 & 4,92 & 4,73 & 4,88 \\
\hline \multirow{3}{*}{$\begin{array}{l}\text { Traditional Cool Season Sports Turf } \\
\text { Mixture }\end{array}$} & 12 & 3,58 & 3,51 & 3,38 & 3,33 & 3,45 \\
\hline & 22 & 3,88 & 3,90 & 3,22 & 3,05 & 3,51 \\
\hline & 32 & 3,82 & 3,42 & 3,09 & 2,97 & 3,32 \\
\hline Mean & & 3,76 & 3,61 & 3,23 & 3,11 & 3,43 \\
\hline \multirow{3}{*}{ General Mean } & 12 & 4,40 & 4,50 & 4,38 & 4,27 & 4,39 \\
\hline & 22 & 4,63 & 4,62 & 4,39 & 4,27 & 4,48 \\
\hline & 32 & 4,61 & 4,46 & 4,36 & 4,28 & 4,43 \\
\hline Mean & & 4,54 & 4,53 & 4,38 & 4,27 & 4,43 \\
\hline
\end{tabular}

Intensive weed infestation occurred in sports field mixture and increasing rate of invasion were observed with the decreasing mowing height, especially during the stress conditions of hot summer season of Mediterranean ecology. Sports turf mixture option, containing cold resistant cool season turf grass type Poa pratensis, Festuca rubra var. rubra, Festuca rubra var. commutata and Festuca ovina, was highly and negatively being affected from the hot and dry conditions of Mediterranean summer in the experimental area (Zorer et al., 2004; Yilmaz and Avcioglu, 2000; Beard, 1973;). Due to the empty patches of during crops in late spring and summer, cover scores of sports turf option decreased and further reduction was occurred with the decreasing height of mowing. These findings were similar with the research results of Volterrani and Magni (2004) in Italy under Mediterranean ecological conditions.

\section{CONCLUSION}

Results indicated that, 60\% Festuca arundinacea + $40 \%$ Lolium perenne mixture displayed the best performance in terms of various turf quality traits. $32 \mathrm{~mm}$ cutting height practices performed better than others and $22 \mathrm{~mm}$ cutting height practice had the best texture. $12 \mathrm{~mm}$ cutting height was detrimental effect on the turf grasses tested and needed expensive maintenance precautions except $60 \%$ Festuca arundinacea $+40 \%$ Lolium perenne mixture.

The mixture of $60 \%$ Festuca arundinacea $+40 \%$ Lolium perenne under $22 \mathrm{~mm}$ cutting height practices was the best option under Mediterranean conditions in terms of sport field characteristics. Traditional cool season sports turf mixture was the poorest option for this type of ecologies.

\section{ACKNOWLEDGEMENT}

Research study (1120130) funded by The Scientific and Technological Research Council of Turkey (TUBITAK).

\section{LITERATURE CITED}

Acikgoz, N., E. Ilker and A. Gokcol. 2004. Assessment of biological research on the computer. Izmir: Ege University, TOTEM, Meta Press.

Anonymous,

2014. https://mevbis.mgm.gov.tr/mevbis/ui/index.html\#/Workspac e

Avcioglu, R. 1997. Turf Technique (Turf Establishment \& Management). Izmir: Ege University Press.

Baker, S.W. and P.M. Canaway. 1993. Concepts of playing quality: criteria and measurement. International Turfgrass Society Research Journal. 20(7): 172-181.

Beard, J.B., 1973. Turfgrass Science and Culture. Englewood Cliffs, N, J. Printice Hall, London.

Bilgili, U. and E. Acikgoz. 2011. Effects of slow-release fertilizers on turf quality in a turf mixture, Turkish Journal of Field Crops, 16(2): 130-136.

Brosnan, J.T., A.S. McNitt and T.J. Serensits. 2009. Effect of varying surface characteristics on the hardness and traction of baseball field playing surfaces. International Turfgrass Society Research Journal. 11:1-11.

Demiroglu, G., H. Geren, B. Kir and R. Avcioglu. 2010. Performances of some cool season turfgrass cultivars in Mediterranean environment: II. Festuca arundinaceae Schreb., Festuca ovina L., Festuca rubra spp. rubra L., Festuca rubra spp. trichophylla Gaud and Festuca rubra spp. commutata Gaud., Turkish Journal of Field Crops. 15(2): 180-187.

Dernoeden, P. H., M.J. Carrol and J. M. Crouse. 1993. Weed management and tall fescue quality as influenced by mowing, nitrogen and herbicides. Crop Sci. 33: 1055-1061.

FIFA. 2005. The FIFA quality concept for football turf. FIFA Marketing XTVAG, Grafenciuweg 2, P.O. Box 4250, Switzerland. 
FIFA. 2009a. The FIFA quality concept for football turf, handbook of requirements May edition. FIFA Marketing XTVAG, Grafenciuweg 2, P.O. Box 4250, Switzerland, pp: 24.

FIFA. 2009b. The FIFA quality concept for football turf, handbook of test methods May 2009 edition. FIFA Marketing XTVAG, Grafenciuweg 2, P.O. Box 4250, Switzerland, pp: 42.

Harivandi, M.A., V.A. Gibeault, M.J. Henry, L. Wu, P.M. Geisel and C.L. Unruh. 2008. Turfgrass selection for the home landscape. http://anrcatalog.ucdavis.edu/pdf/8035.pdf, (Accessed May 01, 2019)

Huang, B. and H. Gao. 2000. Root physiological characteristics associated with drought resistance in tall fescue cultivars. Crop Sci. 40: 196-203.

Kir, B., R. Avcioglu, G. Demiroglu and A. Simic. 2010. Performances of some cool season turfgrass species in Mediterranean environment: I. Lolium perenne L., Festuca arundinacea Schreb., Poa pratensis L., Turkish Journal of Field Crops. 15(2): 174-179

Martinello, P. and D. Andrea. 2006. Cool-season turf grass species adaptability in Mediterranean environments and quality traits of varieties. European Journal of Agronomy. Vol. 25(3), pp: 234-242.

Miele, S., M. Volterrani, S. Magni, and M. Gaetani. 2002. Winter quality of tall fescue turfs, effect of renovation technique and nitrogen fertilization, Diparimento di Agronomia e Gestione dell' Agroecosistema, Universita di Pisa. Ital. J. Argon. 6(2): 97-101.

Miller, G.L. 2004. Analysis of soccer field surface hardness. Acta Hortic. 661, 287-294 DOI: 10.17660/ActaHortic.2004.661.36.

Moore, R.W. and N.E. Christians. 1989. Tall fescue management study. 1989 Iowa Turfgrass Research Report. p. 28-29.

Morris, K.N. and R.C. Shearman. 1998. NTEP Turfgrass Evaluation Guidelines, In NTEP Turfgrass Evaluation Workshop, Beltsville, MD, 5p.

Orchard, J. 2002. Is there a relationship between ground and climatic conditions and injuries in football. Sports Med.; 32 (7):419-432.

Ozkan, S.S., B. Kir and R. Avcioglu. 2014. Effect of mowing heights on the performances of some turf alternatives in Mediterranean ecology. 24th International Scientific-Expert Conference of Agriculture and Food Industry. pp. 337-340.
Powell, A.J. Jr and L.D. Tapp. 1988. Tall fescue variety evaluations. Kentucky Turfgrass Research. p. 6-12.

Reicher, Z.J. and C.S. Throssell. 1991. Influence of seeding rate, nitrogen, and mowing height on establishment of turf-type tall fescue. Agronomy Abstracts. p.181.

Salisbury, F. B. and C. W. Ross. 1992. Plant Physiology. Wadsworth Pub. Com., Inc., Belmont, California-USA.

Salman, A. and R. Avcioglu. 2008. Effect of different fertilizer levels on some cool and warm season turfgrass on turf performances. Ege University Graduate School of Natural and Applied Science. PhD Thesis. Bornova-Izmir (in Turkish).

Salman, A., R. Avcioglu, M. Y1lmaz and G. Demiroglu 2011. Performances of newly introduced Festuca arundinacea Schreb. cultivars versus Lolium perenne L. in a Mediterranean environment, Turkish Journal of Field Crops. 16(2): 215-219.

Saunders, N., D. Twomey and L. Otage. 2011. Clegg hammer measures and human external landing forces: is there a relationship? International Journal of Sports Science and Engineering. Vol. 5(4), pp: 231-236.

Steel, R.G.D., J.H. Torrie. 1980. Principles and Procedures of Statistics. A biometrical approach. 2nd edition. McGrawHill, New York, USA, pp. 20-90.

Uzun, P. and U. Bilgili. 2011. Effects of wastewater sludge on growth of perennial ryegrass (Lolium Perenne L.). Turkish Journal of Field Crops. 16(2): 203-209.

Volterrani, M. and S. Magni. 2004. Species and growing media for sports turfs in Mediterranean area. Acta Hortic. 661, 359364 DOI: 10.17660/ActaHortic.2004.661.48.

Watschke, T.L. and R.E. Schmidt. 1992. Ecological aspects of turf communities. Waddington, D.V., Carrow, R.N. And Shearman, C.R. (Eds.). Turfgrass, American Society of Agronomy, Inc. Agronomy. (32): 129-174.

Yilmaz, M. and R. Avcioglu. 2000. Investigations on seed yield and turf properties of some grasses grown for turfgrass and erosion control purposes in Tokat, Turkey, Ege University Graduate School of Natural and Applied Science. PhD Thesis. Bornova-Izmir (in Turkish).

Zorer, S., I. Hosaflioglu and H.I. Yilmaz. 2004. Determination of proper nitrogen fertilization application times in turffgrass. J. Agric. Sci. 14(1): 27-34 . 